\title{
Surgical treatment results and pathological features in pediatric occult tight filum syndrome
}

\author{
Jeff Julian ${ }^{1}$, Michael Punsoni ${ }^{2}$, John Donahue ${ }^{3}$, Ed Stopa ${ }^{4}$, Petra M Klinge ${ }^{5^{*}}$ \\ From Hydrocephalus 2015 \\ Banff, Canada. 18-21 September 2015
}

\section{Introduction}

Occult tight filum terminale syndrome (OTCS) is defined as a clinical syndrome of tethered cord and without "classic" radiographic evidence of low lying conus and/or fatty filum.

\section{Methods}

A consecutive series of 11 children (2-17 years) diagnosed with tethered cord syndrome (Triad of neurological, urological and orthopedic findings) since 2010, a non-diagnostic MRI, underwent microsurgical resection of the filum. Presenting symptoms and symptoms most responsive to surgery, imaging and pathology of the filum were analyzed.

\section{Results}

OTSC show the overall improvement in all dimensions of the clinical syndrome, e.g. scoliosis, walking and falling spells, incontinence and overall activity level due to improved pain. Increased tone in the lower extremities and foot deformities appeared as a negative predictor of improvement. Associated syringohydromyelia did not show any change in the 1 year follow-up MRI despite marked clinical improvement. Pathology shows a variety of features including "nerve twigs".

\section{Conclusions}

The accuracy of the clinical TRIAD consisting of symptoms in the dimensions of bowel and bladder dysfunction, orthopedic and neurological signs to define "occult filum terminale or occult tight filum syndrome" and the accuracy of the clinical TRIAD to predict surgical success of detethering has to be explored and proven in a prospective fashion.

\footnotetext{
* Correspondence: pklinge@lifespan.org

${ }^{5}$ Neurosurgical Department, Rhode Island Hospital, USA

Full list of author information is available at the end of the article
}

\author{
Authors' details \\ 'Neurosurgical Department, Rhode Island Hospital, USA. ${ }^{2}$ Neuropathology, \\ Rhode Island Hospital, USA. ${ }^{3}$ Neuropathology, Rhode Island Hospital, USA. \\ ${ }^{4}$ Neuropatholgy, Rhode Island Hospital, USA. ${ }^{5}$ Neurosurgical Department, \\ Rhode Island Hospital, USA.
}

Published: 18 September 2015

\section{References}

1. Wikkelso C, Hellstrom P, Klinge PM, Tans JT: European i NPHMSG: The European iNPH Multicentre Study on the predictive values of resistance to CSF outflow and the CSF Tap Test in patients with idiopathic normal pressure hydrocephalus. J Neurol Neurosurg Psychiatry 2013, 84:562-568.

2. Brinker T, Stopa E, Morrison J, Klinge P: A new look at cerebrospinal fluid circulation. Fluids and barriers of the CNS 2014, 11:10.

doi:10.1186/2045-8118-12-S1-P21

Cite this article as: Julian et al:: Surgical treatment results and pathological features in pediatric occult tight filum syndrome. Fluids and Barriers of the CNS 2015 12(Suppl 1):P21.
Submit your next manuscript to BioMed Central and take full advantage of:

- Convenient online submission

- Thorough peer review

- No space constraints or color figure charges

- Immediate publication on acceptance

- Inclusion in PubMed, CAS, Scopus and Google Scholar

- Research which is freely available for redistribution
() Biomed Central 